\title{
Penerapan Metode Topsis Pemilihan Role Model pada Pengadilan Negeri Asahan
}

\author{
William Ramdhan ${ }^{1^{*}}$, Wan Mariatul Kifti², Waji Datur Rahmi Sipahutar ${ }^{3}$ \\ ${ }^{123}$ Program Studi Sistem Informasi, STMIK Royal, Indonesia \\ Email: ${ }^{1 *}$ william.ramdhan052@gmail.com, ${ }^{2}$ kifti.inti@gmail.com, ${ }^{3}$ wajidaturahmi.02@gmail.com,
}

\begin{tabular}{|c|c|}
\hline open & $\begin{array}{l}\text { Abstrak } \\
\text { Role Model menentukan seseorang yang menia }\end{array}$ \\
\hline $\begin{array}{l}\text { Histori Artikel: } \\
\text { Diajukan: } 20 \text { June } 2021 \\
\text { Disetujui: } 25 \text { June } 2021 \\
\text { Dipublikasi: } 30 \text { June } 2021\end{array}$ & $\begin{array}{l}\text { tertentu, di mana perilakunya tersebut diikuti oleh pegawai yang lain Pemilihan } \\
\text { kandidat terbaik sebagai Role Model, pada pengadilan negeri saat ini dilakukan } \\
\text { secara konvensional dimana sering kali terjadi kesalahan dan kecurangan pada } \\
\text { saat penilaian kinerja pegawai karena penilaian yang bersifat subyektif, }\end{array}$ \\
\hline $\begin{array}{l}\text { Kata Kunci: } \\
\text { Sistem Pendukung } \\
\text { Keputusan, TOPSIS, Role } \\
\text { Mode, Pengadilan Negeri } \\
\text { Kisaran, Visual Basic }\end{array}$ & $\begin{array}{l}\text { pendataan kinerja pegawai yang tidak benar dalam penilaian serta membutuhkan } \\
\text { waktu yang cukup lama pada proses penyeleksian calon kandidat terpilih } \\
\text { sehingga mempengaruhi efektifitas kinerja sebuah instansi. Metode yang } \\
\text { digunakan pada penelitian ini adalah metode Topsis (Technique for Other } \\
\text { References by Similarity to Ideal Solution) merupakan salah satu dari metode }\end{array}$ \\
\hline $\begin{array}{l}\text { Digital Transformation } \\
\text { Technology (Digitech) is an } \\
\text { Creative Commons License This } \\
\text { work is licensed under a } \\
\text { Creative Commons Attribution- } \\
\text { NonCommercial } 4.0 \\
\text { International (CC BY-NC 4.0). }\end{array}$ & $\begin{array}{l}\text { Sistem Pendukung Keputusan yang penerapan metode akan membandingkan } \\
\text { setiap kandidat berdasarkan kriteria standar penilaian yang baik. TOPSIS } \\
\text { mampu memberikan bentuk model sistem pendukung keputusan dalam bentuk } \\
\text { sebuah hirarki fungsional dengan input utamanya persepsi manusia. } \\
\text { Implepentasi TOPSIS pada Pengadilan Negeri Kisaran mempermudah } \\
\text { mengelola bagian kepegawaian dalam proses pemilihan agen perubahan sebagai } \\
\text { role model yang lebih akurat dan juga penyajian laporan penilaian pegawai yang } \\
\text { lebih efektif dan efisien. }\end{array}$ \\
\hline
\end{tabular}

\section{PENDAHULUAN}

Pada era globalisasi teknologi komputer memegang peranan yang sangat penting untuk membantu proses aktivitas kerja di setiap perusahaan maupun instansi baik dari lembaga pemerintah maupun swasta. Pengadilan Negeri Kisaran merupakan sebuah instansi pemerintahan yang memanfaatkan perkembangan teknologi untuk mempermudah serta meningkatkan kinerja setiap pegawainya [6]. Dengan pesatnya perkembangan teknologi juga berdampak pada program program kerja yang dibuat instansi untuk memberikan penilaian terhadap kinerja pegawai, misalnya dalam program pemilihan Role Model dalam sebuah instansi.

Role Model menentukan seseorang yang menjadi teladan/panutan atas peran tertentu, di mana perilakunya tersebut diikuti oleh pegawai yang lain dimana semua yang dibawah intasnsi tersebut ikut terlibat dalam pemilihan tersebut (pimpinan atau pejabat atau bisa juga pegawai biasa) [9]. Dalam bahasa agama, role model setara maknanya dengan uswatun hasanah atau teladan yang baik. Berdasarkan Surat Keputusan Ketua Pengadilan Negeri tentang Role Model merupakan pengembangan perilaku dan budaya kerja di dalam bidang profesionalisme, integritas dan kejujuran Pengadilan Negeri tahun 2018.

Pemilihan kandidat terbaik sebagai Role Model, pada pengadilan negeri saat ini dilakukan secara konvensional dimana sering kali terjadi kesalahan dan kecurangan pada saat penilaian kinerja pegawai karena penilaian yang bersifat subyektif, pendataan kinerja pegawai yang tidak benar dalam penilaian serta membutuhkan waktu yang cukup lama pada proses penyeleksian calon kandidat terpilih sehingga mempengaruhi efektifitas kinerja sebuah instansi.

Berangkat dari permasalahan tersebut, maka peneliti melakukan sebuah penelitian guna mendapatkan solusi dalam menentukan agen perubahan sebagai Role Model untuk memberikan kemudahan pada Pengadilan Negeri Kisaran mengatasi adanya kesalahan dalam memberikan penilaian terhadap kinerja dan kedisiplinan pegawai melalui penerapan teknologi informasi [7].

Topsis (Technique for Other References by Similarity to Ideal Solution) yang merupakan salah satu dari metode Sistem Pendukung Keputusan (SPK). Melalui penerapan metode ini, peneliti akan membandingkan setiap kandidat berdasarkan kriteria standar penilaian yang baik. Kriteria tersebut seperti tanggung jawab, disiplin, profesionalisme, integritas, dan kejujuran. Sehingga akan menghasilkan sebuah informasi tentang Agen Perubahan sebagai Role Model berdasarkan kriteria - kriteria yang telah dibuat. Melalui rancangan sistem tersebut dapat digunakan untuk menentukan Agen Perubahan sebagai Role Model, maka Pengadilan Negeri Kisaran mampu menilai kinerja pegawai secara efektif dan efisien sebagai tolak ukur dalam pengambilan keputusan [2]. 


\section{STUDI LITERATUR}

\section{TOPSIS (Technique for Other References by Similarity to Ideal Solution)}

TOPSIS merupakan metode multikriteria yang digunakan untuk mengidentifikasi himpunan dari beberapa alternatif berdasarkan minimalisasi simultan dari jarak titik ideal dan memaksimalkan jarak dari titik terendah [2][5][8]. TOPSIS digunakan karena metode memberikan bentuk model sistem pendukung keputusan dalam bentuk sebuah hirarki fungsional dengan input utamanya persepsi manusia, yakni dalam hal ini adalah orang yang mempunyai jobdesk dalam menentukan pemilihan agen perubahan sebagai Role Model atau orang yang mengerti permasalahan tersebut.

TOPSIS memiliki kekuatan dibandingakan metode yang lain yakni sebagai berikut:[3]

a. Metode Topsis merupakan salah satu metode yang simple dan konsep rasional yang mudah dipahami.

b. Metode Topsis mampu untuk mengukur kinerja relatif dalam membentuk form matematika sederhana.

Secara umum, prosedur TOPSIS mengikuti langkah-langkah sebagai berikut: [1][7][8][10]

a. Membuat matriks keputusan yang ternormalisasi

$$
r i j=\frac{x i j}{\sqrt{\sum_{i}^{m}=j^{x i j^{2}}}}
$$

b. Menghitung nilai normalisasi terbobot

$$
\text { Yij = wi.rij }
$$

c. Menentukan matriks solusi ideal positif dan matriks solusi ideal negatif

$$
\begin{aligned}
& A^{+}=\left(y_{1}^{+}, y_{2}^{+}, \ldots, y_{n}^{+}\right) \\
& A^{-}=\left(y_{1}^{-}, y_{2}^{-}, \ldots, y_{n}^{-}\right)
\end{aligned}
$$

d. Menentukan jarak antara nilai setiap alternatif dengan matriks solusi ideal positifdan negatif. Jarak antara alternatif (Ai) dengan solusi ideal positif dirumuskan sebagai:

$$
D i^{+}=\sqrt{\sum_{j=i}^{n}\left(y i^{+}-y i j\right)^{2}}
$$

Jarak antara alternatif (Ai) dengan solusi ideal negatif dirumuskan sebagai

$$
D i^{-}=\sqrt{\sum_{j=i}^{n}\left(y i^{+}-y i j\right)^{2}}
$$

e. Menentukan nilai preferensi untuk setiap alternatif. Nilai preferensi untuk setiap alternatif (Vi) diberikan sebagai :

$$
V i=\frac{D i^{-}}{D i^{-}+D i^{+}}
$$

Nilai Vi yang lebih besar menunjukkan bahwa alternatif(Ai) yang nilainya paling tinggi lebih dipilih

\section{Role Model}

role model dimana "person who serves as an example, whose behavior is emulated by others" dalam Indonesia memiliki pengertian seseorang yang memberikan teladan dan berperilaku yang bisa dicontoh oleh orang lain. Sosok yang menjadi role model adalah mereka yang memiliki jiwa kepemimpinan karena Pemimpin akan selalu dijadikan bahan pembicaraan oleh anggota anggota dari suatu organisasi. Sebagai pemimpin mereka harus mampu mengarahkan sekaligus memberikan contoh yang baik bagi anggota anggota nya dengan berperilaku yang positif dan menginspirasi orang lain [4].

Dengan demikian role model adalah orang (pimpinan atau pejabat atau bisa juga pegawai biasa) yang menjadi teladan/panutan atas peran tertentu, di mana perilakunya tersebut diikuti oleh pegawai yang lain. Dalam bahasa agama, role model setara maknanya dengan uswatun hasanah atau teladan yang baik.

\section{METODE}

Untuk mempermudah penyusunan penelitian ini, maka perlu adanya susunan kerangka kerja (frame work) untuk menjelaskan tujuan dari penelitian. Kerangka kerja ini merupakan langkah-langkah yang akan dilakukan dalam penyelesaian masalah yang akan dibahas. Adapun kerangka kerja penelitian yang di gunakan seperti terlihat pada gambar 1: 


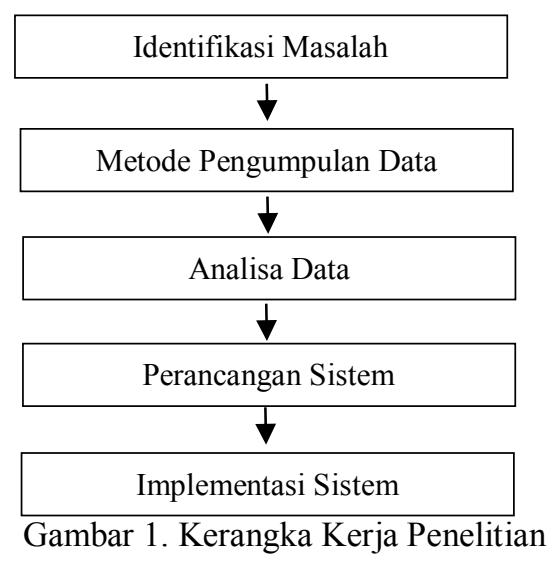

1. Identifikasi Masalah

Identifikasi masalah disebut juga dengan Problem Identification adalah suatu proses dan hasil pengenalan masalah atau inventarisasi masalah dengan kata lain identifikasi masalah adalah salah satu proses penelitian yang bisa dikatakan langkah paling penting diantara langkah - langkah proses yang lain. Permasalahan yang dihadapi oleh insatansi pengadilan negeri kisaran adalah sulitnya dalam menentukan role model yang ada di instasi tersebut secara efektif dan efisien.

2. Metode Pengumpulan Data

Metode pengumpulan data adalah teknik atau cara yang dilakukan oleh peneliti untuk mengumpulkan data. Pengumpulan data dilakukan guna memperoleh informasi yang dibutuhkan dalam rangka mencapai tujuan penelitian. Data yang diguanakan pada penelitian ini menggunakan data pegawai yang ada dibawah intasnsi pengadilan negeri kisaran meliputi: pimpinan atau pejabat maupun pegawai biasa

3. Analisa Data

Analisa data adalah suatu kegiatan mengolah data hasil penelitian menjadi informasi yang dapat digunakan untuk mengambil kesimpulan dalam suatu penelitian. Adapun cara pengambilan kesimpulan bisa dengan hipotesis maupun etimasi hasil. Data yang didapatkan di olah dan dianalisis dengan menggunakan TOPSIS guna menghasilkan hasilkan keputusan yang terbaik.

4. Perancangan Sistem

Perancangan sistem adalah sebuah kegiatan merancang dan menentukan cara mengolah informasi dari hasil analisa sistem sehingga dapat memenuhi kebutuhan dari pengguna termasuk diantaranya perancangan user interface, data dan aktivitas proses. Berdasarkan data yang telah dianalisis tadi meranncang sistem pendukung keputusan agar sistem yang dibangun dapat dimanfaatkan oleh pengadilan negeri kisaran.

5. Implementasi Sistem

Implementasi sistem adalah tahap penerapan sistem yang akan dilakukan jika sistem disetujui termasuk program yang telah dibuat pada tahap perancangan sistem dan juga uji coba sistem agar siap untuk dioperasikan.

\section{HASIL}

Dalam memulai perhitungan metode Topsis dibutuhkan kriteria serta sub kriteria sehinggal dapat dilakukan kalkulasi terhadap bobot- bobot kriteria serta sub kriteria yang sudah ditetapkan dalam pemilihan agen perubahan sebagai Role Model di Pengadilan Negeri Kisaran.

Berikut tabel data kriteria dan sub kriteria pada sistem pendukung keputusan pemilihan agen perubahan sebagai Role Model di Pengadilan Negeri Kisaran:

Tabel 1. Tabel Kriteria

\begin{tabular}{lc}
\hline \multicolumn{1}{c}{ Nama Kriteria (K) } & Bobot Kriteria \\
\hline Profesionalisme & 5 \\
Integritas & 4 \\
Kejujuran & 4 \\
Tanggung Jawab & 3 \\
Disiplin & 3 \\
\hline
\end{tabular}




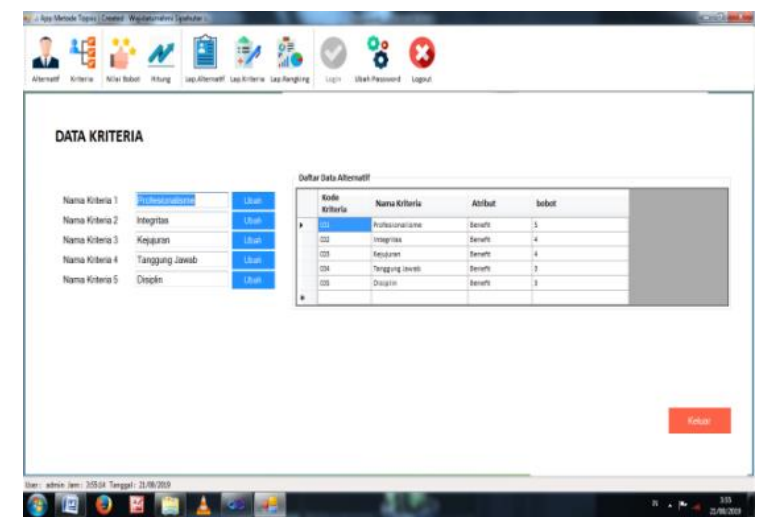

Gambar 2. Halaman Data Kriteria

Tabel 2. Tabel Sub Kriteria

\begin{tabular}{lc}
\hline \hline \multicolumn{1}{c}{ Nama Kriteria } & Bobot Kriteria \\
\hline Tidak Baik & 1 \\
Kurang Baik & 2 \\
Cukup Baik & 3 \\
Baik & 4 \\
Sangat Baik & 5 \\
\hline
\end{tabular}

Dalam perhitungan kali ini kita memiliki matriks dan bobot tiap calon, sebagai berikut:

Tabel 3. Tabel Bobot Alternatif Calon

\begin{tabular}{cccccc}
\hline \hline Alternatif & $(\mathrm{K} 1)$ & $(\mathrm{K} 2)$ & $(\mathrm{K} 3)$ & $(\mathrm{K} 4)$ & $(\mathrm{K} 5)$ \\
\hline Nelly & 4 & 2 & 3 & 3 & 3 \\
Ahmad & 3 & 3 & 4 & 4 & 1 \\
Miduk & 5 & 3 & 3 & 3 & 2 \\
Antoni & 2 & 4 & 4 & 3 & 3 \\
Yohanna & 2 & 4 & 3 & 5 & 1 \\
Tuti & 3 & 5 & 3 & 4 & 3 \\
Helmi & 1 & 4 & 3 & 5 & 3 \\
Darius & 5 & 2 & 4 & 3 & 2 \\
Sri Amiati & 1 & 3 & 5 & 4 & 2 \\
Adellyn & 4 & 3 & 2 & 3 & 3 \\
\hline Pembagi & 10,5 & 10,8 & 11,0 & 12,1 & 7,7 \\
\hline
\end{tabular}

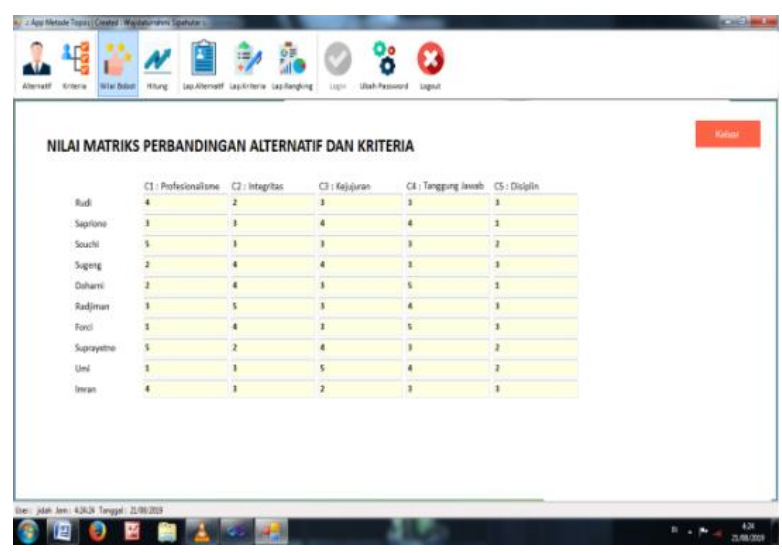

Gambar 3. Nilai Bobot

Untuk mencari nilai Pembagi (X) dengan mengambil data kriteria tiap calon seperti pada rumus berikut:

Nilai $\mathrm{X}=\sqrt{C(i)^{2}+\cdots \cdot C(n)^{2}}$

Dimana: $\mathrm{C}(\mathrm{i})=$ Nilai data pada kriteria

$\mathrm{C}(\mathrm{n})=$ Nilai data terakhir pada kriteria 
Contoh: $X(A 1)=\sqrt{4^{2}+3^{2}+5^{2}+2^{2}+2^{2}+3^{2}+1^{2}+5^{2}+1^{2}+4^{2}}$

$$
=10,48808848
$$

Setelah mendapatkan nilai X maka kita dapat malakukan langkah selanjutnya. Yang perlu kita lakukan selanjutnya adalah mencari nilai matriks keputusan ternormalisasi dimana rumusnya adalah dengan membagikan setiap matriks bobot calon dengan nilai $\mathrm{X}$ tiap kriteria. Seperti pada rumus berikut:

$\mathrm{R}(\mathrm{i})=\frac{C(i)}{X(n)}$

Dimana: R (i) = Nilai matriks keputusan ternormalisasi

C (i) $=$ Nilai Matriks kriteria

$\mathrm{X}(\mathrm{i})=$ Nilai Jumlah matriks kriteria

Contoh: $\mathrm{R}(1,1)=\frac{4}{10,48808848}$

$$
=0,381385036
$$

Dan seterusnya sehingga didapatkan hasil matriks keputusan ternormalisasi seperti pada tabel berikut:

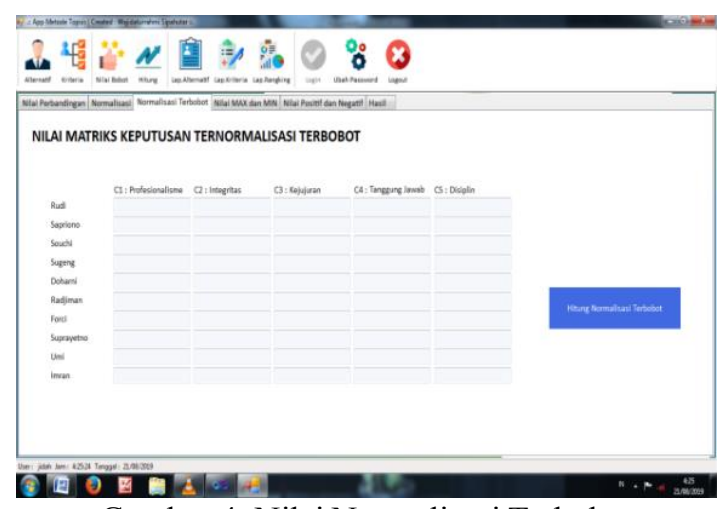

Gambar 4. Nilai Normalisasi Terbobot

Selanjutnya menentukkan nilai maksimum dan minimum dari setiap Alternatif dari semua kriteria dengan cara menghitung nilai alternatif mana yang memiliki nilai tertinggi sebagai nilai Max, dan menghitung nilai alternatif mana yang memiliki nilai terendah sebagai nilai Min. Seperti yang dijelaskan pada tabel berikut:

Tabel 6. Tabel Menghitung Nilai Maksimum dan Minimum

\begin{tabular}{cccccc}
\hline \hline & A1 & A2 & A3 & A4 & A5 \\
\hline MAX & 2,384 & 1,849 & 1,810 & 1,254 & 1,172 \\
MIN & 0,477 & 0,7340 & 0,724 & 0,753 & 0,391 \\
\hline
\end{tabular}

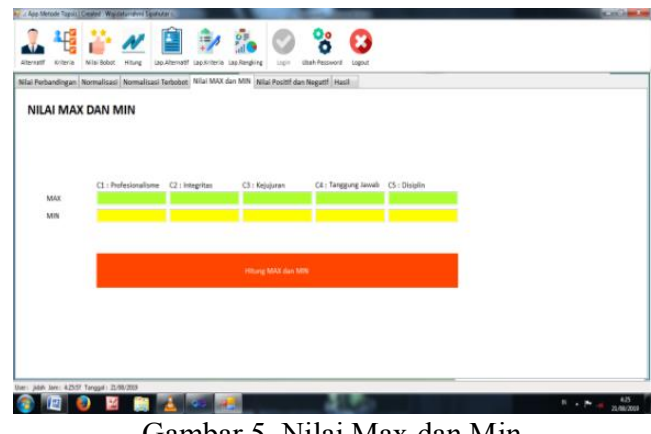

Gambar 5. Nilai Max dan Min

Selanjutnya mencari solusi nilai ideal positif dan nilai ideal negatif dimana mencari nilai solusi ideal positif rumusnya adalah dengan mengurangkan nilai bobot ternormalisasi tiap calon dengan nilai tertinggi dari nilai bobot ternormalisasi tiap kriteria lalu dijumlahkan dengan nilai kriteria lainnya dan kemudian diakarkan. Seperti pada rumus berikut:

$\begin{array}{cl}D^{+}(i)=\sqrt{(Y(i)-\operatorname{Maks}(Y(i)))^{2}+\cdots+(Y(n)-\operatorname{Maks}(Y(n)))^{2}} \\ \text { Dimana: } \mathrm{D}^{+}(\mathrm{i}) & =\text { Nilai Ideal Positif } \\ \mathrm{Y}(\mathrm{i}) & =\text { Nilai Matriks Keputusan Ternormalisasi } \\ \text { Maks (Y(i)) } & =\text { Nilai Tertinggi pada Matriks Kriteria }\end{array}$


Contoh :

$$
\begin{aligned}
\mathrm{D}^{+}(\mathrm{i})= & \sqrt{\begin{array}{c}
(1,906925178-2,38365647 x)^{2}+(0,739600262-1,849000653)^{2}+(1,08642895- \\
1,81071492)^{2}+(0,752617809-1,254363015)^{2}+(1,1717002-1,1717002)^{2}
\end{array}} \\
& =1,49478439
\end{aligned}
$$

Untuk mencari solusi ideal negatif juga memiliki rumus yang sama dengan solusi ideal positif hanya saja dikurangkan dengan nilai bobot-bobot ternormalisasi tiap kriteria yang terendah. Untuk lebih jelas perhatikan contoh sebagai berikut :

$$
\begin{aligned}
& D^{-}(i)=\sqrt{(Y(i)-\operatorname{Min}(Y(i)))^{2}+\cdots+(Y(n)-\operatorname{Min}(Y(n)))^{2}} \\
& \text { Dimana: } \mathrm{D}^{-}(\mathrm{i}) \quad=\text { Nilai Ideal Negatif } \\
& \mathrm{Y}(\mathrm{i}) \quad=\text { Nilai Matriks Keputusan Ternormalisasi } \\
& \text { Contoh: } \\
& \text { Min }(\mathrm{Y}(\mathrm{i}))=\text { Nilai Terendah pada Matriks Kriteria } \\
& D^{-}(i)= \\
& \begin{array}{l}
\sqrt{\begin{array}{c}
(1,906925178-0,4767331295)^{2}+(0,739600262-0,739600262)^{2}+(1,08642895- \\
0,72428597)^{2}+(0,752617809-0,752617809)^{2}+(1,1717002-0,39056673)^{2}
\end{array}} \\
=1,66936263
\end{array}
\end{aligned}
$$

Selanjutnya dilakukan perhitungan sehingga semua calon memiliki nilai solusi ideal positif dan nilai ideal negatif seperti pada tabel berikut:

Tabel 7. Tabel Nilai Ideal Positif dan Ideal Negatif

\begin{tabular}{lcc}
\hline Alternatif & Nilai Ideal Positif & Nilai Ideal Negatif \\
\hline Nelly & 1,49478439 & 1,66936263 \\
Ahmad & 1,503447223 & 1,27803375 \\
Miduk & 1,214861859 & 2,01415136 \\
Antoni & 1,60159373 & 1,38168047 \\
Yohanna & 1,821254056 & 1,07572165 \\
Tuti & 1,223363452 & 1,71584214 \\
Helmi & 2,073090914 & 1,24099711 \\
Darius & 1,328987357 & 2,0768958 \\
Sri Amiati & 2,097343944 & 1,23796585 \\
Adellyn & 1,485381229 & 1,67104045 \\
\hline
\end{tabular}

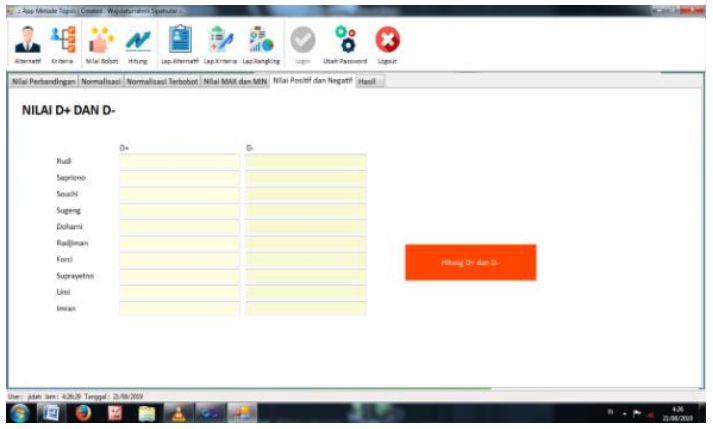

Gambar 6. Nilai Ideal Positif dan Negatif

Setelah mendapatkan nilai ideal positif dan ideal negatif, langkah selanjutnya adalah langkah terakhir untuk mendapatkan nilai perangkingan. Adapun rumus untuk mendapatkan nilai rangking tiap calon adalah dengan menggunakan rumus:

$\mathrm{V}=\frac{D i^{-}}{D i^{-}+D i^{+}}$

$$
\begin{array}{ll}
\text { Dimana: } & =\text { Nilai Rangking } \\
& \mathrm{D}^{+}(\mathrm{i})=\text { Nilai Ideal Positif } \\
\mathrm{D}^{-}(\mathrm{i})=\text { Nilai Ideal Negatif }
\end{array}
$$


$\mathrm{V} 1=\frac{1,66936263}{1,66936263+1,49478439}=0,527586935$

Selanjutnya dilakukan perhitungan hingga semua calon memiliki nilai rangking, sehingga akan diperoleh nilai hasil rangking tiap calon seperti pada tabel berikut:

Tabel 8. Tabel Nilai Rangking

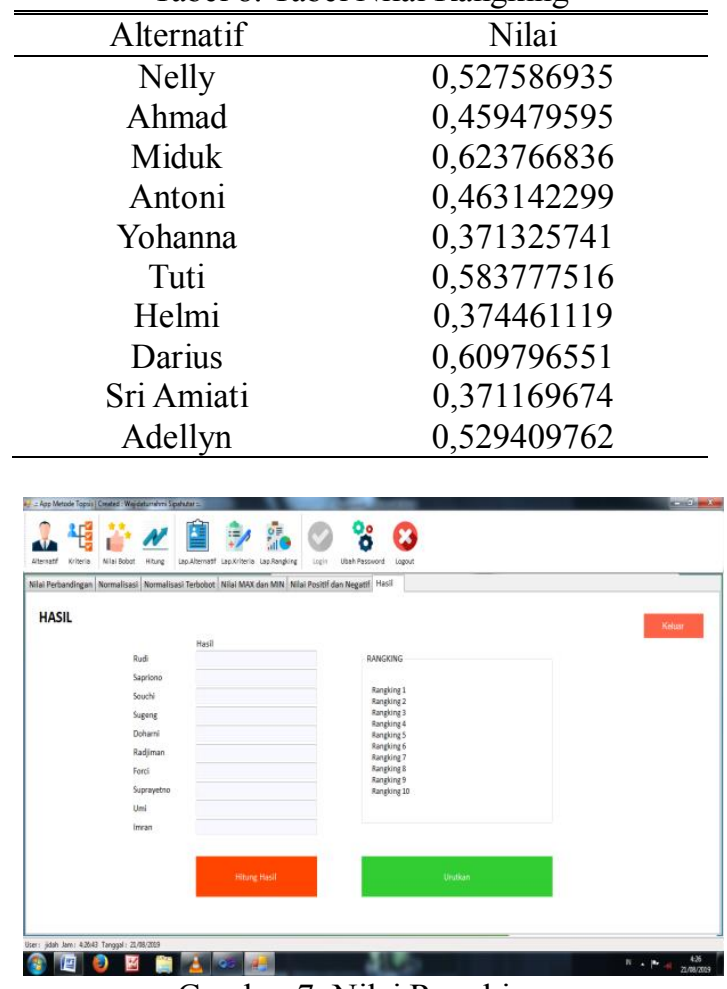

Gambar 7. Nilai Rangking

Pada tabel diatas dapat dilihat bahwa nilai Souchi memiliki nilai tertinggi diantara nilai calon yang lain, sehingga Miduk dinyatakan terpilih sebagai calon Role Model di Pengadilan Negeri Kisaran yang paling sesuai dengan kriteria yang ditetapkan oleh Instansi.

\section{KESIMPULAN}

Pemilihan agen pada Pengadilan Negeri Kisaran sebagai role model dengan mengimplementasikan, Sistem Pendukung Keputusan telah dirancang menjadi solusi bagi Pengadilan Negeri Kisaran untuk mempermudah mengelola bagian kepegawaian dalam proses pemilihan agen perubahan sebagai role model yang lebih akurat dan juga penyajian laporan penilaian pegawai yang lebih efektif dan efisien.

\section{REFERENSI}

[1] D. Jollyta. (2018). TOPSIS Technique for Selecting of Property Development Location. Software Engineering, 6(1), $20-26$. https://doi.org/10.11648/j.se.20180601.14

[2] Gunawan, V. S., \& Yunus, Y. (2021). Sistem Penunjang Keputusan dalam Optimalisasi Pemberian Insentif terhadap Pemasok Menggunakan Metode TOPSIS. Jurnal Informatika Ekonomi Bisnis, 3, 101-108. https://doi.org/10.37034/infeb.v3i3.86

[3] K. Nasution and L. Hanum. (2020). Penerapan Metode Technique for Order By Similarity To Ideal Solution ( Topsis ) Dalam Menentukan Game Online Paling Digemari. Buletin Utama Teknik, 15(2), 142-146.

[4] Kadir, A., \& Junaidin. (2019). Desain Reformasi Birokrasi Melalui Role Model Pelayanan Publik Berbasis Smart Pada Pemerintahan Kota Bima (Studi pada Dinas Penanaman Modal dan Pelayanan Terpadu Satu Pintu (DPMPTSP) Kota Bima. Jurnal Administrasi Negara, 15(2). https://jurnal.fdk.uinsgd.ac.id/index.php/reputation/article/download/67/512/ Ii. ILKOM Jurnal Ilmiah, 9(3), 274-281. https://doi.org/10.33096/ilkom.v9i3.156.274-281 
[6] Muljadi, A., Khumaidi, A., \& Chusna, N. L. (2020). Implementasi Metode TOPSIS Untuk Menentukan Karyawan Terbaik Berbasis Web Pada PT . Mun Hean Indonesia. Jurnal Ilmiah Merpati, 8(2), 101-112.

[7] Nababan, D., Rahim, R., \& Teknologi Medan, I. (2018). Sistem Pendukung Keputusan Reward Bonus Karyawan Dengan Metode Topsis. Journal Information System Development (ISD), 3(1), 2528-5114. https://ejournal.medan.uph.edu/index.php/isd/article/view/185

[8] Risnawati, R., \& Manurung, N. (2019). Sistem Pendukung Keputusan Dalam Penentuan Mitra Jasa Pengiriman Barang Terbaik Di Kota Kisaran Menggunakan Metode Topsis. JURTEKSI (Jurnal Teknologi Dan Sistem Informasi), 5(2), $133-138$. https://doi.org/10.33330/jurteksi.v5i2.357

[9] Sulistyowati, M., \& Widyastuti, I. (2017). Model Konseptual Faktor Yang Mempengaruhi Keputusan Berwirausaha (Pendekatan Role Model Theory). ProBank, 2(1), 25-38. https://doi.org/10.36587/probank.v2i1.129

[10] Wibisono, G., Amrulloh, A., \& Ujianto, E. (2019). Penerapan Metode Topsis Dalam Penentuan Dosen Terbaik. ILKOM Jurnal Ilmiah, 11(2), 102-109. https://doi.org/10.33096/ilkom.v11i2.430.102-109 